\title{
POTENSI DAMPAK LINGKUNGAN DALAM AUDIT KETIDAKSESUAIAN PEMANFAATAN RUANG (KASUS KECAMATAN KASIHAN KABUPATEN BANTUL)
}

\author{
Lina Wahyuni, Fakultas Teknik Lingkungan \\ Email: linawahyuniananda@gmail.com
}

\begin{abstract}
ABSTRAK
Tujuan penelitian ini untuk memperoleh hasil analisis dampak lingkungan dalam audit tata ruang di sebagian Kecamatan Kasihan Kabupaten Bantul. Kecepatan pertumbuhan alih fungsi lahan dan perkembangan sebaran bangunan fisik seperti permukiman, industri, jasa dan niaga yang tidak terkendali dan tidak sesuai dengan peruntukan pemanfaatan ruang, menjadi suatu permasalahan yang dihadapi di sebagian wilayah penelitian. Kasus yang sering dijumpai terutama pada kawasan bantaran sungai, yang seharusnya dilindungi, dimanfaatkan sebagai permukiman, bangunan wisata, industri, perkantoran dan niaga. Demikian pula pada kawasan konservasi atau ruang terbuka hijau sebagai sumber air dan penyimpan sumber air permukaan dapat berubah menjadi kawasan hunian.

Desakan-desakan terhadap alam, juga dapat menyebabkan maraknya bencana alam. Sehingga audit tata ruang diperlukan untuk mengetahui kesesuaian pemanfaatan ruang. Metode yang digunakan dalam penelitian ini dengan menggunakan analisis spasial dan analisis dampak lingkungan. Analisis spasial digunakan untuk mengetahui ketidaksesuaian pemanfaatan ruang, sedangkan analisis dampak lingkungan digunakan untuk mengetahui dampak lingkungan atas adanya ketidaksesuaian pemanfaatan ruang yang dihasilkan dari analisis spasial tersebut. Hasil yang diperoleh yaitu terdapat ketidaksesuaian pemanfaatan ruang dengan potensi dampak yang ditimbulkan yakni berupa: peningkatan jumlah timbulan air limbah, peningkatan timbulan sampah, perubahan debit banjir.
\end{abstract}

Kata kunci: audit, analisis spasial, dampak lingkungan, ketidaksesuaian pemanfaatan ruang.

\section{POTENTIALS OF THE ENVIRONMENTAL IMPACT IN AUDIT UNEMPLOYMENT OF SPACE UTILIZATION (CASE OF KASIHAN SUBDISTRICT, BANTUL REGENCY).}

\begin{abstract}
The purpose of this study was to obtain the results of an environmental impact analysis in a spatial audit in part of Kasihan Subdistrict, Bantul Regency. The speed of growth of land use change and the development of the distribution of physical buildings such as settlements, industries, services and commerce that are not controlled and not in accordance with the allotment of spatial use, become a problem encountered in some
\end{abstract}


research areas. Cases that are often encountered, especially in riverbank areas, which should be protected, are used as settlements, tourist buildings, industries, offices and businesses. Likewise in conservation areas or green open spaces as water sources and surface water storage sources can be turned into residential areas.

Pressures on nature, can also cause natural disasters. So that a spatial audit is needed to determine the suitability of spatial use. The method used in this study uses spatial analysis and environmental impact analysis. Spatial analysis is used to determine the spatial mismatch, while the environmental impact analysis is used to determine the environmental impact of the spatial mismatch resulting from the spatial analysis. The results obtained are that there is a discrepancy in the use of space with the potential impact that is generated in the form of: an increase in the amount of waste water generation, an increase in waste generation, changes in flood discharge.

Keywords: audit, spatial analysis, environmental impact, spatial mismatch.

\section{A. PENDAHULUAN}

\author{
Pertumbuhan penduduk \\ dalam suatu wilayah perkotaan \\ akan seiring dengan peningkatan \\ kebutuhan ruang kota. Kota \\ sebagai perwujudan geografi selalu \\ mengalami perubahan dari waktu \\ ke waktu. Dua faktor utama yang \\ yang sangat berperan adalah faktor \\ penduduk (demografis) dan faktor \\ aspek-aspek kependudukan \\ (Yunus, 1987).
}

Kota Yogyakarta tidak dapat menampung seluruh kegiatan dengan semakin berkembangnya penduduk atas berbagai aktivitasnya, dikarenakan luas wilayah yang secara adminitrasi terbatas (Yogitama, 2015). Akibatnya terjadi perambatan kegiatan ke wilayah pinggiran, diantaranya ke sebagian Kecamatan Kasihan yang berada di dalam Kawasan Perkotaan
Yogyakarta (KPY). Hal tersebut dapat diketahui dengan adanya kenampakan fisik kekotaan yang merembet kearah luar kota. Sehingga di sebagian wilayah Kecamatan Kasihan mengalami perubahan baik secara fisik, ekonomi maupun sosial (Setiyadi, 2005).

Adanya transformasi atas kegiatan di pinggiran kota menjadi salah satu penyebab terjadinya alih fungsi lahan. Dimana alih fungsi lahan tersebut berpotensi tidak sesuai dengan peruntukan pemanfaatan ruang, seperti yang diatur dalam rencana tata ruang yang ada (Raharjo, 2015).

Ketidaksesuaian pemanfaatan ruang berpotensi menimbulkan dampak lingkungan maupun mempengaruhi performa ruang yang ada sebelumnya. Sehingga diperlukan audit tata ruang untuk 
mengetahui

ketidaksesuaian

pemanfaatan ruang.

\section{B. TINJAUAN PUSTAKA}

1. Konsep Tata Ruang.

Undang-undang tata ruang menyebutkan bahwa Ruang adalah wadah yang meliputi ruang darat, ruang laut, dan ruang udara, termasuk ruang di dalam bumi sebagai satu kesatuan wilayah, tempat manusia dan makhluk lain hidup, melakukan kegiatan, dan memelihara kelangsungan hidupnya.

Penataan harus dilakukan terhadap ruang yang ada, agar dapat memberikan manfaat yang maksimal untuk makhluk hidup dan masyarakat yang ada di dalamnya. Sedangkan tata ruang adalah wujud struktural dan pola ruang. Sementara itu, penataan ruang adalah suatu sistem proses perencanaan tata ruang, pemanfaatan ruang, dan pengendalian pemanfaatan ruang.

Dasar hukum bagi pelaksanaan tata ruang adalah Undang-Undang Nomor 26 Tahun 2007. Undang undang tersebut berisi sekumpulan kaidah hukum, asas, dan pranata yang mengatur hak, kewajiban, tugas,

Gambar 1. Lokasi Kajian.

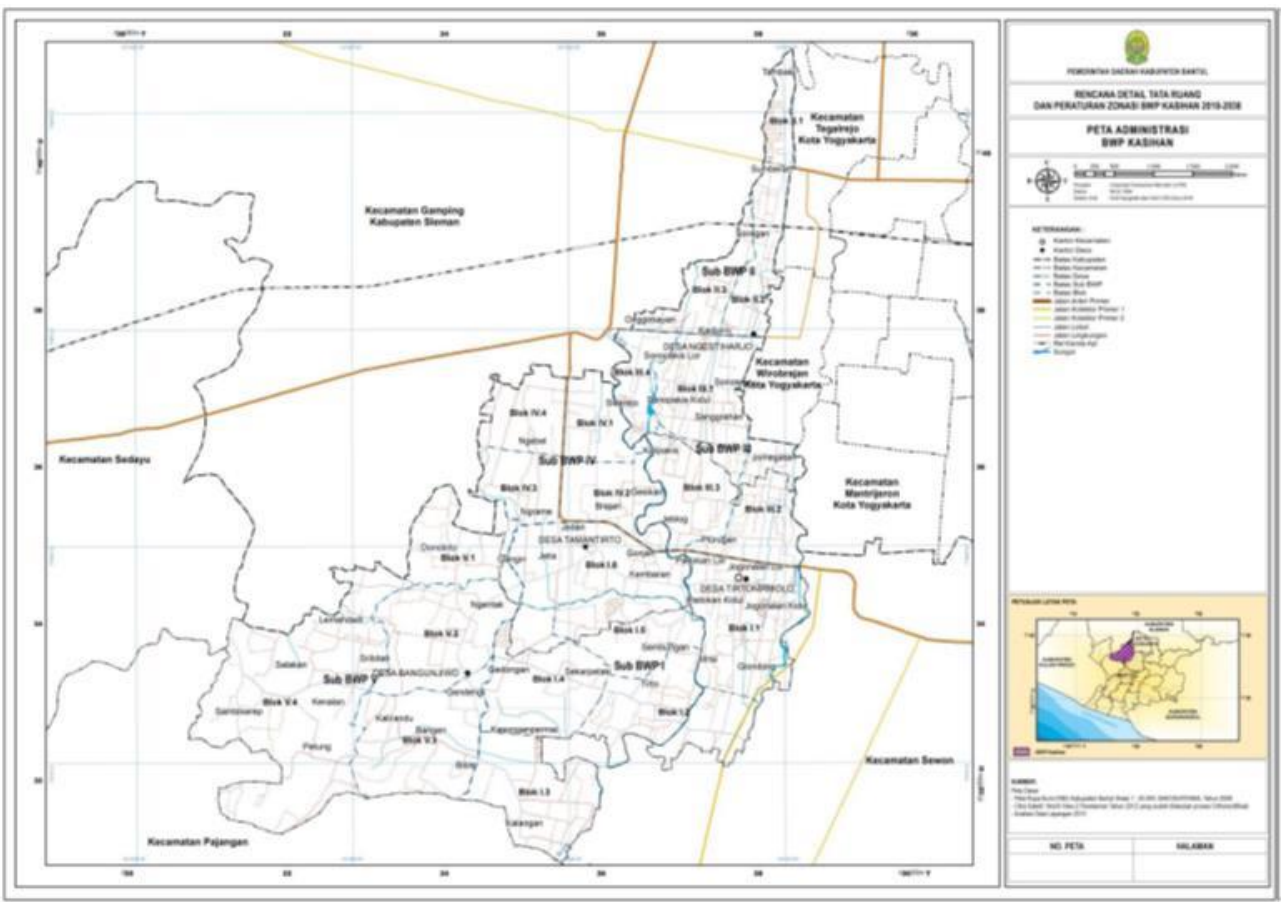

Sumber: Bappeda Bantul, 2018. 
wewenang pemerintah serta hak dan kewajiban masyarakat.

\section{Rencana Tata Ruang}

Kabupaten Bantul.

Rencana Tata Ruang Wilayah (RTRW) memberikan informasi penggunaan lahan pada pembangunan suatu wilayah. Rencana Tata Ruang Wilayah juga berperan penting dalam menentukan letak-letak dan pengaturan tata wilayah dalam suatu daerah.

Sesuai dengan Rencana Tata Ruang Wilayah Kabupaten Bantul, maka Kecamatan Kasihan sebagai bagian dari wilayah Kabupaten Bantul harus menjaga keserasian, keterpaduan pembangunan, dan pengembangan wilayahnya.

Kabupaten Bantul merupakan pusat pertumbuhan dan pusat kegiatan bagi wilayah sekitarnya, yang menjadi bagian dari Kawasan Perkotaan Yogyakarta yang melayani lingkup regional perlu menata ruang sehingga kualitas ruang dapat terjaga keberlanjutannya.

Dalam rangka melaksanakan pembangunan wilayah Kabupaten Bantul secara terpadu, lestari, optimal, seimbang dan serasi sesuai dengan karakteristik, fungsi, dan predikatnya, berpedoman pada perencanaan, pemanfaatan, dan pengendalian ruang di wilayah Kabupaten Bantul.

Kecamatan Kasihan sebagai salah satu kecamatan di Kabupaten Bantul, yangmana sebagian wilayahnya masuk dalam Kawasan Perkotaan Yogyakarta telah tersedia peraturan daerah mengenai Rencana Detil Tata Ruang (RDTR) dan Peraturan Zonasi, sebagai rencana detil yang digunakan sebagai acuan dalam pemanfaatan ruang serta perijinan.

Dalam kaitannya dengan audit tata ruang, kesesuaian pemanfaatan ruang mengacu pada perda RDTR tersebut, diantaranya secara spasial tertuang rencana struktur ruang, rencana pola ruang. Gambar 2 diatas adalah rencana pola ruang yang tertuang di dalam RDTR Kecamatan Kasihan Kabupaten Bantul.

\section{Penggunaan Lahan}

Sumber daya alam sangat penting bagi kehidupan manusia. Salah satu contoh sumberdaya alam yaitu lahan. Lahan merupakan suatu sumber daya alam yang mempunyai peranan penting dalam produksi. Lahan juga digunakan sebagai tempat hidup manusia dalam melakukan segala aktivitasnya (Handayani, 2013).

Penggunaan lahan adalah segala campur tangan manusia baik secara permanen maupun secara psikis terhadap kumpulan sumberdaya alam dan sumber daya buatan dengan tujuan untuk mencukupi kebutuhan material maupun spiritual atau keduaduanya. Pemanfaatan citra satelit yang utama yaitu untuk mendapatkan informasi tematik penggunaan lahan. 


\section{Konsep Kota}

Kota adalah bentang budaya yang ditumbuhkan oleh unsur-unsur alami dengan gejala pemusatan kehidupan yang cukup besar dan corak kehidupan yang cukup heterogen dan materialistis jika dibandingkan dengan daerah dibelakangnya (Bintarto,1977). Dilihat secara kualitatif perkembangan kota lebih mengarah kepada sektor non agraris seperti tempat pusat usaha, pemerintahan, jasa dan hiburan dengan tingkat mobilitas penduduk yang tinggi.

\section{Lingkungan Hidup}

Lingkungan hidup mempunyai arti penting dalam kehidupan manusia, seperti tercantum dalam Undang-undang nomor 32 tahun 2009 disebutkan pengertian lingkungan hidup adalah kesatuan ruang dengan semua benda, daya, keadaan, dan makhluk hidup, termasuk manusia dan perilakunya, yang mempengaruhi kelangsungan perikehidupan dan kesejahteraan manusia serta makhluk hidup lain

Ruang lingkup lingkungan hidup Indonesia meliputi ruang, Tempat Negara Kesatuan Republik Indonesia yang berwawasan nusantara dalam melaksanakan kedaulatan, hak berdaulat, dan yurisdiksinya. Manusia dalam pengertian mengenai lingkungan hidup merupakan salah satu unsur makhluk hidup, seperti yang tercantum dalam Undang-undang lingkungan hidup, dan di sini manusia memiliki pengaruh terhadap kelangsungan kehidupan makhluk hidup lainnya yang secara naluriah tidak mencemari, merusak atau menguras lingkungan. Kehidupan makhluk hidup lain selain manusia tidak tergantung akan ada atau tidaknya manusia tetapi sebaliknya kehidupan manusia bergantung pada makhluk hidup lainnya seperti tumbuhan dan hewan.

\section{METODE PENELITIAN}

Analisis dengan pertampalan kesesuaian pemanfaatan ruang dalam rencana tata ruang (Syahid, 2003). dilakukan dengan melakukan pertampalan terhadap penggunaan lahan eksisting dengan peta rencana pola ruang beserta dengan ketentuan pemanfaatannya, sesuai dengan Peraturan Menteri Agraria dan Tata Ruang nomor 17 tahun 2017 tentang pedoman audit tata ruang.

Data yang digunakan berupa data sekunder berupa dokumen hasil kajian, data-data statistik dan tekstual dari instansi terkait, data peta, data citra, maupun data primer yang diambil langsung dari lapangan..

Ketentuan pemanfaatan dapat berupa ketentuan kegiatan dan peruntukan ruang yang terdapat dalam rencana rinci, atau ketentuan umum peraturan zonasi yang terdapat pada Rencana Tata Ruang Wilayahkabupaten/kota.Sebelum 
melakukan proses pertampalan, dilakukan hal-hal sebagai berikut:

1. Menyamakan skala ketelitian peta penggunaan lahan eksisting dengan peta rencana tata ruang yang digunakan.

2. Menyamakan

pengelompokan penggunaan lahan.

Dalam melakukan pertampalan dapat dilakukan dengan dua cara, yaitu:

1. Pemeriksaan bertahap; dan 2 . Menggunakan rumus fungsi berdasarkan atribut ketentuan pemanfaatan.

Sedangkan analisis dampak lingkungan dilakukan dengan membandingkan perbedaan nilai parameter lingkungan atau dalam hal ruang dinyatakan dalam perubahan skala kualitas lingkungan dalam skala numerik (skala 1, 2, 3, 4, 5) sebagai berikut (Fandeli,1995)

\section{HASIL DAN PEMBAHASAN}

Rencana Pola Ruang RDTR Kasihan dapat dibedakan atas: kebun, ladang, sawah, peternakan, kolam, perumahan, jalan, fasilitas kesehatan, fasilitas pendidikan, fasilitas ibadah, industri, perdagangan dan jasa, perkantoran, cagar budaya, lapangan olah raga, RTH dan penggunaan lahan campuran. Luasan lahan yang dominan adalah zona perumahan $(48,54 \%)$, zona lainnya yakni gabungan dari ladang, kebun, sawah $(23,31 \%)$, zona sarana pelayanan umum $(2,02 \%)$, industri $(4,57 \%)$, perdagangan dan jasa $(10,65 \%)$,

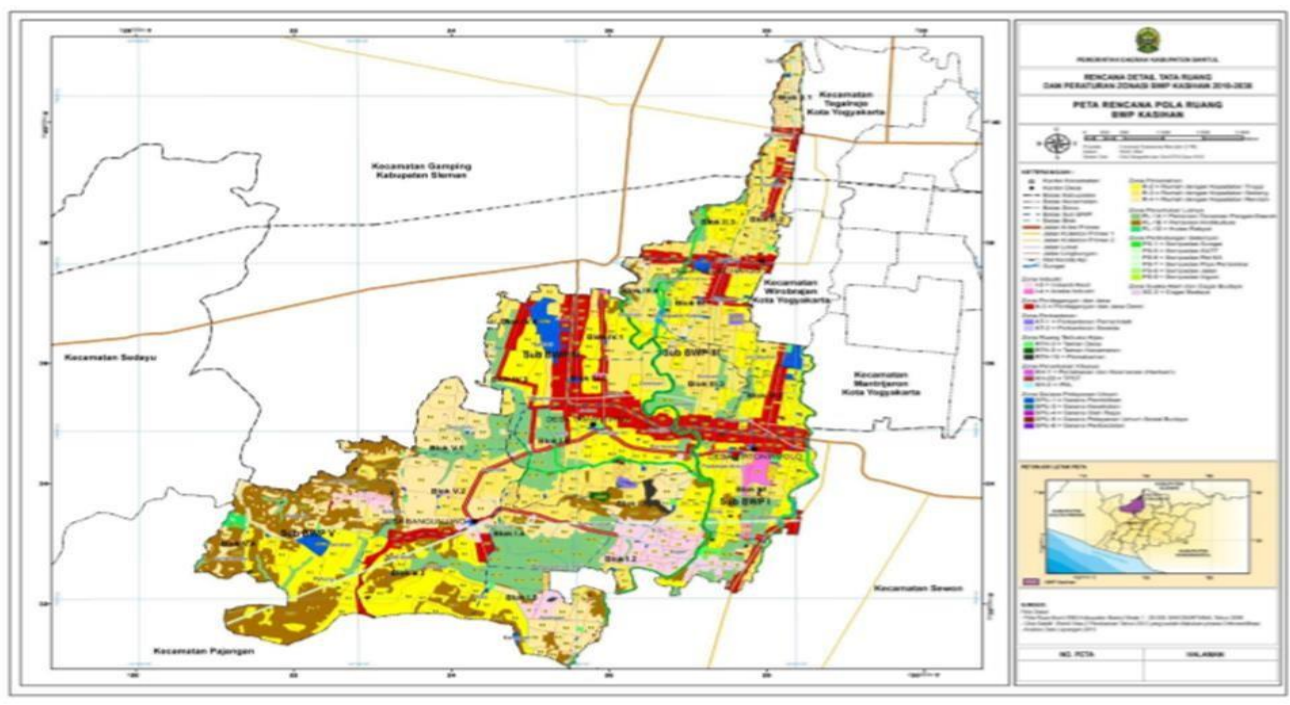

Gambar 2. Rencana pola ruang RDTR Kecamatan Kasihan Kabupaten Bantul.

ini dampak lingkungan antara kondisi Sumber: Bapedda Bantul, 2018 eksisting dan rencana pola serta dalam luasan yang kecil terdapat RTH lapangan dan makam 
$(0,96 \%)$, perkantoran $(0,27 \%)$ dan cagar budaya $(0,06 \%)$.

Khusus untuk RTH, jika dihitung dengan sempadan jalan, sungai, rel kereta api, rest area dan fasilitas social, fasilitas umum perumahan pengembang maka jumlahnya mencapai $22,14 \%$.

Hasil analisis ketidaksesuaian pemanfaatan ruang terhadap perda RDTR diperoleh 4 objek yang tidak sesuai dengan rencana pola ruang, yang dibangun setelah adanya perda RDTR.

Keempat objek tersebut adalah:

1. Galeri Kerajinan.

2. Pertokoan

3. Lahan Perumahan

4. Pergudangan
Dampak lingkungan yang berpotensi mucul akibat adanya ketidaksesuaian pemanfaatan ruang tersebut adalah:

1. Peningkatan jumlah timbulan air limbah

2. Peningkatan timbulan sampah.

3. Terpengaruhinya performa ruang

1. Peningkatan Jumlah Timbulan Air Limbah.

Pada tabel 1 dapat diketahui timbulan sampah pada pemanfaatan ruang eksisting sebesar 16,23 $\mathrm{m} 3 /$ hari. Sedangkan timbulan sampah pada rencana pola ruang sebesar $10,5 \mathrm{~m} 3 /$ hari

Tabel 1. Jumlah Timbulan Air Limbah

\begin{tabular}{|l|c|c|c|}
\hline & $\begin{array}{c}\text { Jumlah } \\
\text { Penghasil }\end{array}$ & Timbulan & Total Timbulan (m3/ hari) \\
\hline $\begin{array}{l}\text { Pemanfaatan ruang } \\
\text { eksisting }\end{array}$ & 415 & $\begin{array}{c}35 \text { liter/ orang/ } \\
\text { hari }\end{array}$ & $\mathbf{1 6 , 2 3}$ \\
\hline Rencana Pola Ruang & 150 & $\begin{array}{c}70 \text { liter/ orang/ } \\
\text { hari }\end{array}$ & $\mathbf{1 0 , 5}$ \\
\hline
\end{tabular}

Sumber: Analisis, 2019

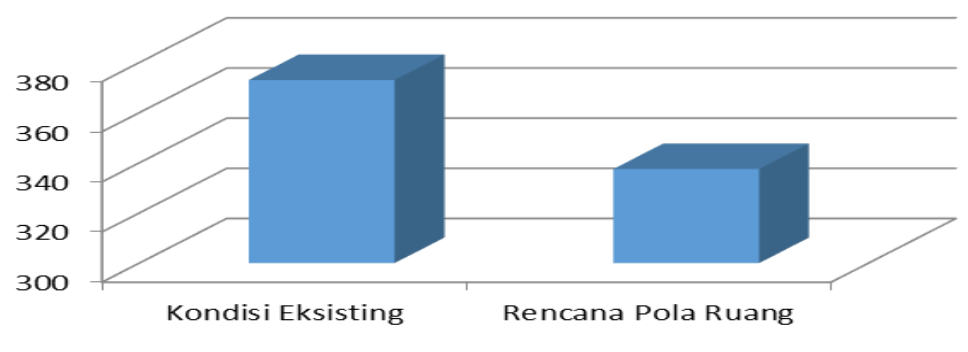

- Total Timbulan (L/ hari)

Gambar 3. Perbandingan Timbulan Air Limbah

Sumber: Analisis, 2019. 


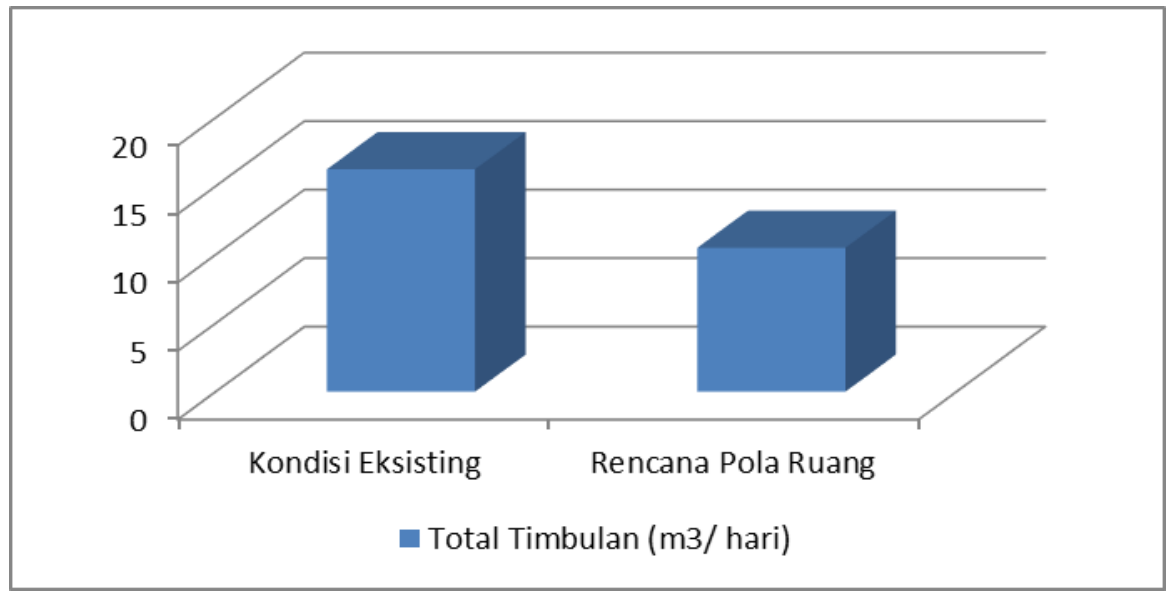

Gambar 4: Timbulan Sampah. Sumber: Analisis, 2019

Tabel 2. Jumlah Timbulan Limbah Padat

\begin{tabular}{|c|c|c|c|c|}
\hline No & $\begin{array}{c}\text { Penghasil } \\
\text { sampah }\end{array}$ & Jumlah penghasil & Timbulan & $\begin{array}{c}\text { Total } \\
\text { timbulan }\end{array}$ \\
\hline $\mathbf{1}$ & Pengunjung & 365 orang & $\begin{array}{c}0,2 \text { Liter/orang. } \\
\text { Hari }\end{array}$ & 73 L/hari \\
\hline $\mathbf{2}$ & Karyawan & 100 orang & 3 Liter/orang. hari & 300 L/hari \\
\hline \multicolumn{3}{|c|}{ Total } & $\mathbf{3 7 3 L} / \mathbf{h a r i}$ \\
\hline $\mathbf{1}$ & $\begin{array}{c}\text { Penghuni } \\
\text { Perumahan } \\
\text { (Pola Ruang) }\end{array}$ & 75 orang & $\begin{array}{l}2,25 \text { Liter/orang. } \\
\text { hari }\end{array}$ & $\mathbf{1 6 5}$ L/hari \\
\hline
\end{tabular}

Sumber: Analisa, 2019

Pada gambar 4 dapat diketahui bahwa kondisi saat ini sebagai bangunan yang tidak sesuai dengan rencana pola ruang, menghasilkan potensi timbulan air limbah yang lebih tinggi dibandingan apabila sesuai dengan peruntukannya.

2. Peningkatan Timbulan Limbah Padat. 
Tabel 3. Performa Ruang

\begin{tabular}{|c|c|c|c|c|c|c|}
\hline & \multicolumn{3}{|c|}{ INDIKATOR } & \multicolumn{3}{|c|}{ PERFORMA RUANG } \\
\hline & $\begin{array}{l}\text { PERLINDUNGA } \\
\text { AWAHANNYA }\end{array}$ & AN TERHADAP KAWASAN & & $\begin{array}{l}\text { A. PERLINDL } \\
\text { BAWAHANN }\end{array}$ & & AN TERHADAP KAWASAN \\
\hline 1 & \begin{tabular}{|lr}
$\begin{array}{l}\text { koefisien } \\
\text { limpasan } \\
(0-0,3)\end{array}$ & rendah \\
\end{tabular} & \multirow{3}{*}{$\begin{array}{l}\text { Nilai Koefisien air limpasan (run } \\
\text { off) SNI-03-2415-199 }\end{array}$} & 3 & \multirow{3}{*}{$\begin{array}{lr}\text { Debit r banjin } \\
\text { dengan koefisien } \\
\text { limpasan tinggi } \\
0,85\end{array}$} & \multirow{3}{*}{1} & \multirow{3}{*}{$\begin{array}{l}\text { Kawasan dilakukan } \\
\text { pengupasan dan melakukan } \\
\text { pembangunan }\end{array}$} \\
\hline 2 & \begin{tabular}{|lr} 
koefisien & air \\
limpasan & sedang \\
$(0,4-0,7)$ & \\
\end{tabular} & & 2 & & & \\
\hline & $\begin{array}{|lr|}\begin{array}{l}\text { koefisien } \\
\text { limpasan } \\
(0,8-1,0)\end{array} & \text { air } \\
\end{array}$ & & 1 & & & \\
\hline \multicolumn{3}{|c|}{ B. PERTANIAN } & & \multicolumn{3}{|l|}{ B. PERTANIAN } \\
\hline 1 & $\begin{array}{l}\text { Menghasilkan } \\
\text { bahan pangan }\end{array}$ & \multirow{3}{*}{$\begin{array}{l}\text { perhitungan } \\
\text { kerugian }\end{array}$} & 3 & \multirow{3}{*}{$\begin{array}{l}\text { Tidak } \\
\text { menghasilkan } \\
\text { bahan pangan }\end{array}$} & \multirow{3}{*}{1} & \multirow{3}{*}{$\begin{array}{l}\text { Pemanfaatan lahan berup: } \\
\text { perdagangan dan jasa }\end{array}$} \\
\hline 2 & $\begin{array}{l}\text { Kurang } \\
\text { menghasilkan } \\
\text { bahan pangan } \\
\end{array}$ & & 2 & & & \\
\hline 3 & \begin{tabular}{|l} 
Tidak \\
menghasilkan \\
bahan pangan \\
\end{tabular} & & 1 & & & \\
\hline \multicolumn{3}{|c|}{ C. KUALITAS LINGKUNGAN } & & \multicolumn{3}{|c|}{ C. KUALITAS LINGKUNGAN } \\
\hline 1 & Sangat Baik & \multirow{5}{*}{$\begin{array}{l}\text { Hasil perbedaan nilai parameter } \\
\text { lingkungan atau dalam hal ini } \\
\text { dampak lingkungan antara } \\
\text { kondisi eksisting dan rencana } \\
\text { pola ruang akan dinyatakan } \\
\text { dalam perubahan skala kualitas } \\
\text { lingkungan dalam skala numerik } \\
\text { (skala } 1,2,3,4,5 \text { ) sebagai } \\
\text { berikut (Fandeli,1995) }\end{array}$} & 5 & \multirow{5}{*}{$\begin{array}{l}\text { 1. Peningkatan } \\
\text { jumlah timbulan } \\
\text { air limbah (skor } \\
\text { 2) } \\
\text { 2. Peningkatan } \\
\text { limbah padat } \\
\text { sampah (skor 3) }\end{array}$} & \multirow{5}{*}{5} & \multirow{5}{*}{$\begin{array}{l}\text { Texiadi peningkatan } \\
\text { kebutuhan air bersih, jumlah } \\
\text { timbulan air limbah dan } \\
\text { limbah padat/ sampah. }\end{array}$} \\
\hline 2 & Baik & & 4 & & & \\
\hline 3 & \begin{tabular}{|l} 
Sedang \\
\end{tabular} & & 3 & & & \\
\hline 4 & Buruk & & 2 & & & \\
\hline 5 & Sangat buruk & & 1 & & & \\
\hline & & & & TOTAL & 7 & \\
\hline
\end{tabular}

Sumber: Analisa, 2019.

Adanya ketidaksesuaian antara kondisi eksisting dengan rencana pola ruang, maka berpotensi menimbulkan sampah yang lebih tinggi yakni 373 L/hari dibandingkan dengan timbulan sampah pada rencana pola ruang yakni $165 \mathrm{~L} / \mathrm{hari}$.

3. Performa Ruang Dengan adanya ketidaksesuaian pemanfaatan ruang, maka debit banjir dengan koefisien limpasan tinggi 0,85 , tidak menghasilkan bahan pangan, peningkatan jumlah timbulan air limbah (skor 2), peningkatan limbah padat/ sampah (skor 3)

\section{E. KESIMPULAN DAN SARAN}

1. Kesimpulan: Bangunan yang didirikan pada beberapa lokasi di Kecamatan Kasihan tidak sesuai dengan rencana pola ruang.

2. Saran: direkomendasikan untuk dilakukan tindakan untuk 
peringatan dan penertiban, supaya dalam memanfaatkan ruang harus memperhatikan tata ruang yang berlaku.

\section{F. DAFTAR PUSTAKA}

Agus Eko Raharjo (2015). Dampak

Konversi Lahan Terhadap

Lingkungan Lahan Pertanian dan Strategi Adaptasi Petani di Kecamatan Mejayan Kabupaten Madiun. Tesis. Universitas Gadjah Mada. Yogyakarta.

Bappeda Kabupaten Bantul (2018).

Rencana Detil Tata Ruang dan Peraturan Zonasi Kecamatan Kasihan Tahun 2018-2038. Chafid Fandeli (1995). Audit Lingkungan. Yogyakarta.

Hadi Sabari Yunus (1987). Permasalahan Daerah Urban Fringe dan Alternatif Pemecahannya. Yogyakarta: Fakultas Geografi Universitas Gadjah Mada..

Kementerian Agraria dan Tata Ruang (2017). Permen No 17 tahun 2017 tentang Pedoman Audit Tata Ruang. Jakarta.

Retna Handayani (2013). Evaluasi Penggunaan Lahan di Kecamatan Bantul
Berdasarkan Rencana Tata Ruang Wilayah. Skripsi. Universitas Gdjah Mada.

Setiaji, I., 2011, Pembuatan Peta Perubahan Penggunaan Lahan Pertanian Tahun 2005 Sampai Tahun 2011, Skripsi, Jurusan Teknik Geodesi, Fakultas Teknik, Universitas Gadjah Mada,Yogyakarta.

Setiyadi, A., 2005, Evaluasi Perubahan Penggunaan Lahan Menggunakan Data Citra Satelit Quickbird 2011 dan Orthofoto 1996 Daerah Ring Road Selatan, Skripsi, Jurusan Teknik Geodesi, Fakultas Teknik, Universitas Gadjah Mada,Yogyakarta.

Syahid, L., 2003, Pemanfaatan Citra Digital Quickbird untuk Evaluasi Rencana Umum Tata Ruang Kota, Skripsi, Jurusan Teknik Geodesi, Fakultas Teknik, Universitas Gadjah Mada, Yogyakarta.

Undang-undang No 26 Tahun 2007 tentang Penataan Ruang.

Yogiatma (2012). Pemanfaatan Citra Worldview II Untuk Identifikasi Kualitas Lingkungan Permukiman di Kecamatan Gondomanan Kota Yogyakarta. 